\section{JURNAL ABDIMAS

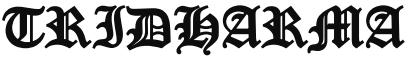

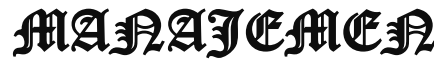

P-ISSN 2715-7105, E-ISSN 2716-070X

Jurnal ABDIMAS Vol. 2,No. 2, April 2021,Hal (80-90)

@Prodi Manajemen Fakultas Ekonomi Universitas Pamulang

Email: abdimasjurnal.unpam@ gmail.com Telp: (021) 741-2566

\title{
PELATIHAN DECOUPAGE UNTUK MENGEMBANGKAN KREATIVITAS DAN MENINGKATKAN PENDAPATAN WARGA BENDA BARU PAMULANG DI MASA PANDEMI
}

\author{
Retno Wulansari, Jeni Andriani, Maswarni, Fitri Sabina, Nopi Oktavianti \\ Dosen Prodi Manajemen Fakultas Ekonomi Universitas Pamulang \\ Email : dosen00568@unpam.ac.id,dosen00436@unpam.ac.id, \\ dosen00381@unpam.ac.id, dosen02019@unpam.ac.id, dosen02481@unpam.ac.id
}

\begin{abstract}
ABSTRAK
Tujuan dari Pengabdian kepada Masyarakat (PKM) ini adalah untuk memberdayakan sumber daya warga kelurahan Benda Baru Pamulang, menuju terwujudnya warga yang kreatif dan terampil, meningkatkan pendapatan warga sehingga terciptanya kesejahteraan warga, serta meningkatkan rasa optimis dan berdaya saing tinggi di masa pandemi Covid-19. Adapun mitra dalam PKM ini adalah RW 06, RW 10 dan RW 12 Kelurahan Benda Baru Pamulang dan LPM (Lembaga Pemberdayaan Masyarakat), yang beralamat di Benda Baru, Jl. H. Rean No. 17, Pamulang, Tangerang Selatan.

Metode yang digunakan dalam PKM ini dalah penyuluhan tentang bagaimana meningkatkan pendapatan bagi para usaha mikro dan kecil dan pelatihan keterampilan untuk meningkatkan kreativitas warga didalam membuat dan menjual produk, yang sesuai dengan kondisi pandemi dan kebutuhan pasar saat ini. Pelatihan ketrampilan yang dilaksanakan, adalah membuat kerajinan ( $c r a f t$ ) dengan media masker kain dengan teknik decoupage, dan memberikan motivasi kepada warga.

Hasil dari pelaksanaan PKM ini, diharapkan warga Benda Baru Pamulang dapat menciptakan produk-produk kreatif yang sesuai dengan kebutuhan dan pasar pada masa pandemi Covid-19, warga dapat membuat produk kerajinan (craft) dengan teknik decoupage, dan warga tetap optimis serta dapat meningkatkan pendapatan di masa pandemi covid-19.
\end{abstract}

\section{Kata kunci: Kreativitas, Pendapatan, Decoupage, Pandemi Covid-19}

\section{ABSTRACT}

The purpose of Community Service (PKM) has to empower the resources of the residents of Benda Baru Pamulang village, towards creating creative and skilled citizens, increased residents incomes so as to create citizen welfare, and increased optimism and high competitiveness during the Covid-19 pandemic. The partners in this PKM were $R W 06, R W$ 10 and RW 12 Kelurahan Benda Baru Pamulang and LPM (Community Empowerment Institution), which was located at Benda Baru, Jl. H. Rean No. 17, Pamulang, South Tangerang.

The method used in this PKM was counseling on how to increase income for micro and small businesses and skills training to increase citizen creativity in making and selling products, which were in accordance with current pandemic conditions and market needs. The skills training carried out was to make crafts using cloth masks using the decoupage technique, and to provide motivation to residents.

As a result of the implementation of this PKM, it expected that the residents of Benda Baru Pamulang could create creative products that were in accordance with the needs and markets during the Covid-19 pandemic, residents could make handicraft products (craft) with 


\section{JURNAL ABDIMAS

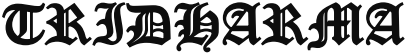 AtA}

P-ISSN 2715-7105, E-ISSN 2716-070X

Jurnal ABDIMAS Vol. 2,No. 2, April 2021,Hal (80-90)

@ Prodi Manajemen Fakultas Ekonomi Universitas Pamulang

Email: abdimasjurnal.unpam@gmail.com Telp: (021) 741-2566

decoupage techniques, and residents remain optimistic and could increase income. during the covid-19 pandemic.

Keywords: Creativity, Income, Decoupage, The Covid-19 Pandemic

\section{PENDAHULUAN}

Pandemi penyakit koronavirus 2019 (coronavirus disease 2019), disingkat COVID-19 adalah penyakit menular yang disebabkan oleh SARS-CoV-2, salah satu jenis koronavirus. Penyakit ini mengakibatkan pandemi koronavirus 20192020. Penderita COVID-19 dapat mengalami demam, batuk kering, dan kesulitan bernapa, sakit tenggorokan, pilek, atau bersin-bersin. Pada penderita yang paling rentan, penyakit ini dapat berujung pada pneumonia dan kegagalan multiorgan. Infeksi menyebar dari satu orang ke orang lain melalui percikan (droplet) dari saluran pernapasan yang sering dihasilkan saat batuk atau bersin. Waktu dari paparan virus hingga timbulnya gejala klinis berkisar antara 1-14 hari dengan rata-rata 5 hari. Berdasarkan situs resmi satuan penanganan Covid-19, yaitu https://covid19.go.id, data per tanggal 17 Oktober 2020, gambar 1. Jumlah terpapar Covid-19 di Indonesia.

\section{Gambar 1: Jumlah Indonesia Terpapar Covid-19 di Indonesia}

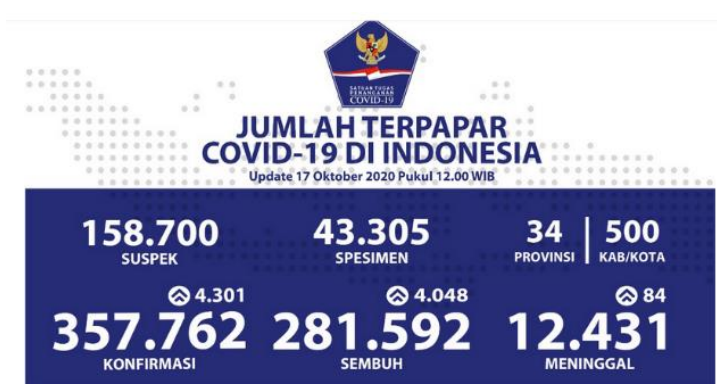

\section{Sumber: www.covid19.go.id}

Pasien terkonfirmasi positif sebanyak 4.301 kasus dan kumulatifnya mencapai 357.762 kasus. Sedangkan jumlah kasus Covid-19 yang masih aktif adalah sejumlah 63.739. Sebaran daerah dengan kasus tertinggi harian berada di DKI Jakarta dengan tambahan harian sebanyak 974 kasus dan kumulatifnya mencapai 93.356 kasus. Jawa Barat kedua tertinggi harian sebanyak 500 kasus dan kumulatifnya sudah menembus angka 30.043 kasus.

Satgas Penanganan Covid-19 menerangkan alasan suatu provinsi menjadi prioritas penanganan. Awalnya hanya ada 8 provinsi prioritas dan saat ini sudah ada 10 provinsi prioritas dalam penanganan Covid19.

Kesepuluh itu diantaranya DKI Jakarta, Jawa Barat, Jawa Tengah, Jawa Timur, Kalimantan Selatan, Sulawesi Selatan, Sumatera Utara, Papua, Bali dan Banten. "Mengapa Banten, karena provinsi ini kasus tertingginya berasal dari kabupaten/kota yaitu Tangerang, Tangerang Selatan dan Kabupaten Tangerang," jelas Juru Bicara Satgas Penanganan Covid-19 Prof. Wiku Adisasmito, menjawab pertanyaan media dalam jumpa pers di Kantor Presiden, Kamis (1/10/2020). Pada 3 daerah di Banten itu kontribusinya $75 \%$ dari seluruh kasus yang ada di provinsi tersebut. Hal itu membuat Banten menjadi salah satu perhatian Satgas Penanganan Covid-19.

Pemerintah telah menerapkan PSBB sesuai dengan Surat Keputusan Menteri Kesehatan Republik Indonesia Nomor HK.01/07/MENKES/249/2020 tentang Penetapan Pembatasan Sosial Berskala Besar di Wilayah Tangerang Selatan yang dimulai dari tanggal 18 April 2020 dan disoalisasikan dimulai tanggal 19 20 April 2020. Kemudian telah dilanjutkan oleh Peraturan Gubernur Banten no 443/kep.161.Huk/2020 tentang penetapan perpanjangan tahap ketiga PSBBdi wilayah Tangerang Selatan di sektor pendidikan, tempat kerja, fasilitas umum dan ibadah, kegiatan budaya sampai transportasi umum, dan disebut paling akhir ini, termasuk penggunaan kendaraan pribadi, hingga protap angkutan moda dua berbasis online.

Dampak pandemi COVID-19 juga menghantam para pengusaha mikro, dari 


\section{JURNAL ABDIMAS

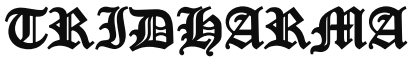

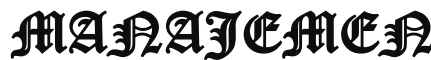

P-ISSN 2715-7105, E-ISSN 2716-070X

Jurnal ABDIMAS Vol. 2,No. 2, April 2021,Hal (80-90)

@Prodi Manajemen Fakultas Ekonomi Universitas Pamulang

Email: abdimasjurnal.unpam@gmail.com Telp: (021) 741-2566 mengalami penurunan pendapatan sampai dengan terancam gulung tikar. Meningkatnya pengangguran imbas dari karyawan yang dirumahkan, karena PSBB. Diperlukan cepat tanggap dari pemerintah setempat dan lembaga masyarakat di wilayahnya untuk dapat mencari solusi dari masalah tersebut.

LPM (Lembaga Pemberdayaan Masyarakat) Kelurahan Benda Baru Pamulang, merupakan mitra pemerintah dalam menampung maupun mewujudkan aspirasi masyarakat untuk pembangunan wilayah di tingkat RT/RW yang beralamat di Benda Baru, Jl. H. Rean No. 17, Pamulang, Tangerang Selatan.

\section{RUMUSAN MASALAH}

Adapun rumusan masalah pengabdian kepada masyarakat ini adalah :

1. Bagaimana memberdayakan sumber daya warga kelurahan Benda Baru Pamulang, menuju terwujudnya warga yang kreatif dan terampil?

2. Bagaimana meningkatkan pendapatan warga, sehingga terciptanya kesejahteraan warga Benda Baru Pamulang?

3. Bagaimana meningkatkan rasa optimis dan berdaya saing tinggi di masa pandemi Covid-19 dan era new normal?

\section{TUJUAN KEGIATAN}

Adapun tujuan dari pengabdian kepada masyarakat ini adalah:

1. Memberdayakan sumber daya warga kelurahan Benda Baru Pamulang, menuju terwujudnya warga yang kreatif dan terampil

2. Meningkatkan pendapatan warga, sehingga terciptanya kesejahteraan warga Benda Baru Pamulang

3. Meningkatkan rasa optimis dan berdaya saing tinggi di masa pandemi Covid-19 dan era new normal

\section{TINJAUAN PUSTAKA \\ Kreativitas}

Berdasarkan kamus KBBI (Kamus

Besar Bahasa Indonesia), pengertian dari kreativita adalah kemampuan untuk mencipta, daya cipta, berkreasi, kekreatifan. Kreativitas juga dapat diartikan sebagai suatu pola pikir atau ide yang timbul secara spontan dan imajinatif, yang merincikan hasil artistik penemuan dan penciptaan baru.

Kreativitas juga merupakan daya atau kemampuan manusia untuk menciptakan sesuatu. Kemampuan ini dapat terkait dengan bidang seni maupun ilmu pengetahuan. Dalam bidang seni, intuisi dan inspirasi sangat berperan besar dan menurut spontanitas lebih tinggi.

Menurut Baron (1969, dalam Munandar, (2009, hlm 21), kreativitas adalah kemampuan untuk menghasilkan atau menciptakan. Menurut Haefele (1962, dalam Munandar, (2009, hlm 21) memaparkan bahwa kreativitas adalah kemampuan untuk membuat kombinasi, beberapa para ahli memaparkan devinisi dari kreativitas. Sedangkan menurut Munandar (1995, hlm 19) mengemukakan bahawa kreativitas adalah hasil interaksi antara individu dan lingkungannya, kemampuan untuk membuat kombinasi baru, berdasarkan data, informasi, unsur-unsur yang sudah ada atau dikenal sebelumnya.

Kreativitas dalam proses dinyatakan sebagai Proses kreativitas menurut Walles dalam Munandar (2009, hlm. 21) ada 4 (empat) tahap, yaitu:

1) Tahap persiapan, seseorang mempersiapkan diri untuk memecahkan masalah dengan belajar berfikir, mencari jawaban, bertanya kepada orang dan sebagainya.

2) Tahap inkubasi, adalah tahap dimana individu seakan-akan melepaskan diri dari masalah tersebut atau tidak memikirkan masalah secara sadar. Mereka melaporkan bahwa gagasan atau inspirasi yang merupakan titik mula dari suatu penemuan atau kreasi baru berasal dari daerah pea-sadar atau timbul dalam keadaan ketidak sadaran penuh.

3) Tahap iluminasi saat timbulnya inspirasi atau gagasan pemecahan masalah baru.

4) Tahap verifikasi atau tahap ealuasi ialah tahap dimana ide atau kreasi baru tersebut harus di uji terhadap realitas. 


\section{JURNAL ABDIMAS

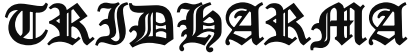

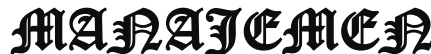

P-ISSN 2715-7105, E-ISSN 2716-070X

Jurnal ABDIMAS Vol. 2,No. 2, April 2021,Hal (80-90)

@Prodi Manajemen Fakultas Ekonomi Universitas Pamulang

Email: abdimasjurnal.unpam@gmail.com Telp: (021) 741-2566
Menurut Carl Rongers dalam Munandar (2009, hlm. 34) tiga kondisi dari pribadi yang kreatif adalah sebagai berikut:

1) Keterbukaan terhadap pengalaman

2) Kemampuan untuk menilai situasi dengan patokan pribadi seseorang (internal locus of evaluation)

3) Kemampuan untuk bereskperimen untuk bermain dengan konsep- konsep.

Rencana inovatif serta produk orisinal mereka telah dipikirkan dengan matang lebih dahulu, dengan mempertibangkan masalah yang mungkin akan timbul dan implikasinya.

Pada pribadi kreatif, jika memiliki kondisi pribadi dan lingkungan yang menunjang, atau lingkungan yang memberi kesempatan atau peluang untuk bersibuk diri secara kreatif maka diprediksikan bahwa produk kreativitasnya akan muncul. Kondisi yang memungkinkan seseorang menciptakan produk kreatif yang bermakna ialah kondisi pribadi dan kondisi lingkungan, yaitu sejauh mana keduanya mendorong (press) seseorang untuk melibatkan dirinya dalam proses (kesibukan, kegiatan) kreatif. Dengan dimilikinya bakat dan ciri-ciri pribadi kreatif, dengan dorongan (internal maupun eksternal) untuk bersibuk diri secara kreatif, maka produkproduk kreatif yang bermakna dengan sendirinya akan timbul.

Menurut Basener dan Treffinger dalam Munandar (2009, hlm. 41) menyarankan bahwa produk kreatif dapat digolongkan menjadi tiga kategori, yaitu:

1. Kebaruan (novelty)

Sejauh mana produk itu baru, dalam hal jumlah dan proses yang baru, teknik baru, bahan baru, konsep baru yang terlibat. Produk itu orisinal dalam arti sangat langka di antara produk-produk yang dibuat oleh orang lain, juga menimbulkan kejutan sebelum memberikan penilaian orang tercengang, dan terakhir produk itu dapat menimbulkan gagasan produk orisinal lainnya.

2. Pemecahan (resolution)

Menyangkut derajat sejauh mana produk itu memenuhi kebutuhan dari situasi bermasalah. Tiga kriteria dalam dimensi ini adalah, bahwa produk itu harus bermakna (valiable) atau memenuhi kebutuhan, logis, dengan mengikuti aturan yang ditentukan dalam bidang tertentu, dan berguna karena dapat diterapkan secara praktis.

3. Elaborasi dan sintesis

Sejauh mana produk itu menggabung unsur-unsur yang tidak sama atau serupa menjadi keseluruhan yang koheren (bertahan secara logis).

\section{Pendapatan}

Terdapat beberapa definisi pendapatan dari sumber ahli dan literatur. Menurut Sukirno (2000), pendapatan merupakan unsur yang sangat penting dalam sebuah usaha perdagangan, karena dalam melakukan suatu usaha tentu ingin mengetahui nilai atau jumlah pendapatan yang diperoleh selama melakukan usaha tersebut. Dalam arti ekonomi, pendapatan merupakan balas jasa atas penggunaan faktor-faktor produksi yang dimiliki oleh sektor rumah tangga dan sektor perusahaan yang dapat berupa gaji/upah, sewa, bunga serta keuntungan/profit (Hendrik, 2011).

$$
\text { Menurut Munandar (2006), }
$$
pengertian pendapatan adalah suatu pertambahan asset yang mengakibatkan bertambahnya owners equity, tetapi bukan karena pertambahan modal baru dari pemiliknya dan bukan pula merupakan pertambahan asset yang disebabkan karena bertambahnya liabilities.

Kondisi seseorang dapat diukur dengan menggunakan konsep pendapatan yang menunjukkan jumlah seluruh uang yang diterima oleh seseorang atau rumah tangga selama jangka waktu tertentu (Samuelson dan Nordhaus, 2002). Definisi lain dari pendapatan adalah jumlah penghasilan yang diperoleh dari hasil pekerjaan dan biasanya pendapatan seseorang dihitung setiap tahun atau setiap bulan. Dengan demikian pendapatan merupakan gambaran terhadap posisi ekonomi keluarga dalam masyarakat. Pendapatan keluarga berupa jumlah keseluruhan pendapatan dan kekayaan keluarga, dipakai untuk membagi keluarga dalam tiga kelompok pendapatan, yaitu: 


\section{JURNAL ABDIMAS

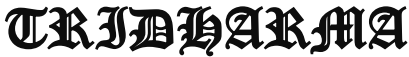

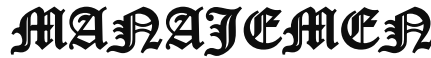

P-ISSN 2715-7105, E-ISSN 2716-070X

Jurnal ABDIMAS Vol. 2,No. 2, April 2021,Hal (80-90)

@Prodi Manajemen Fakultas Ekonomi Universitas Pamulang

Email: abdimasjurnal.unpam@gmail.com Telp: (021) 741-2566 pendapatan rendah, pendapatan menengah dan pendapatan tinggi. Pembagian di atas berkaitan dengan, status, pendidikan dan keterampilan serta jenis pekerja seseorang namun sifatnya sangat relative (Endang Hariningsih dan Rintar Agus Simatupang, 2008).

Sebagaimana pendapat di atas, bahwa pendapatan merupakan gambaran terhadap posisi ekonomi keluarga dalam masyarakat, oleh karenanya setiap orang yang bergelut dalam suatu jenis pekerjaan tertentu termasuk pekerjaan di sector informal atau perdagangan, berupaya untuk selalu meningkatkan pendapatan darihasil usahanya yang digunakan untuk memenuhi kebutuhan hidup keluarganya dan sedapat mungkin pendapatan yang diperoleh dapat meningkatkan taraf hidup keluarganya.

Menurut Sadono Sukirno (2000), pendapatan dapat dihitung melalui tiga cara yaitu:

1. Cara Pengeluaran. Cara ini pendapatan dihitung dengan menjumlahkan nilai pengeluaran/perbelanjaan ke atas barang-barang dan jasa.

2. Cara Produksi. Cara ini pendapatan dihitung dengan menjumlahkan nilai barang dan jasa yang dihasilkan.

3. Cara Pendapatan. Dalam penghitungan ini pendapatan diperoleh dengan menjumlahkan seluruh pendapatan yang diterima.

Pendapatan adalah penerimaan bersih seseorang, baik berupa uang kontan maupun natura. Pendapatan atau juga disebut juga income dari seorang warga masyarakat adalah hasil penjualannya dari faktor-faktor produksi yang dimilikinya pada sektor produksi. Dan sektor produksi ini membeli faktor-faktor produksi tersebut untuk digunakan sebagai input proses produksi dengan harga yang berlaku di pasar faktor produksi. Harga faktor produksi di pasar (seperti halnya juga untuk barangbarang di pasar barang) ditentukan oleh tarik menarik, antara penawaran dan permintaan (Poniwati Asmie, 2008).

Secara garis besar pendapatan digolongkan menjadi tiga golongan (Suparmoko, 2000), yaitu :
1. Gaji dan Upah. Imbalan yang diperoleh setelah orang tersebut melakukan pekerjaan untuk orang lain yang diberikan dalam waktu satu hari, satu minggu maupun satu bulan.

2. Pendapatan dari Usaha Sendiri. Merupakan nilai total dari hasil produksi yang dikurangi dengan biayabiaya yang dibayar danusaha ini merupakan usaha milik sendiri atau keluarga dan tenaga kerja berasal dari anggota keluarga sendiri, nilai sewa kapital milik sendiri dan semua biaya ini biasanya tidak diperhitungkan.

3. Pendapatan dari Usaha Lain. Pendapatan yang diperoleh tanpa mencurahkan tenaga kerja, dan ini biasanya merupakan pendapatan sampingan antara lain, pendapatan dari hasil menyewakan asset yang dimiliki seperti rumah, ternak dan barang lain, bunga dari uang, sumbangan dari pihak lain, pendapatan dari pensiun, dan lainlain.

Menurut Tohar (2003), pendapatan perseorangan adalah jumlah pendapatan yang diterima setiap orang dalam masyarakat yang sebelum dikurangi transfer payment. Transfer Payment yaitu pendapatan yang tidak berdasarkan balas jasa dalam proses produksi dalam tahun yang bersangkutan. Pendapatan dibedakan menjadi:

1. Pendapatan asli yaitu pendapatan yang diterima oleh setiap orang yang langsung ikut serta dalam produksi barang.

2. Pendapatan turunan (sekunder) yaitu pendapatan dari golongan penduduk lainnya yang tidak langsung ikut serta dalam produksi barang seperti dokter, ahli hukum dan pegawai negeri.

\section{Kerajinan Decoupage}

Decoupage adalah seni kerajinan dari Perancis yang masuk ke Indonesia sebelum tahun 2000. Decoupage adalah seni melapis barang dengan menggunakan tisu impor dengan berbagai media yaitu clutch pandan, gantungan kunci, tatakan gelas, kaleng mini, kotak perhiasan, jam kayu, talenan kayu hiasan dinding, gelas kaca, 


\section{JURNAL ABDIMAS

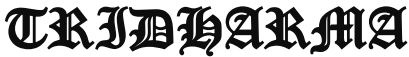 AtA}

P-ISSN 2715-7105, E-ISSN 2716-070X

Jurnal ABDIMAS Vol. 2,No. 2, April 2021,Hal (80-90)

@Prodi Manajemen Fakultas Ekonomi Universitas Pamulang

Email: abdimasjurnal.unpam@gmail.com Telp: (021) 741-2566 botol, kalung mutiara (teknik suspenso), stoples, piring, tas kain, dan kanvas lukis. (Hendraidjat, 2016).

Berdasarkan (Oxpford Dictionary, 2016), Decoupage or découpage is the art of decorating an object by gluing colored paper cutouts onto it in combination with special paint effects, gold leaf and other decorative elements. Commonly, an object like a small box or an item of furniture is covered by cutouts from magazines or from purpose-manufactured papers. Each layer is sealed with varnishes (often multiple coats) until the "stuck on" appearance disappears and the result looks like painting or inlay work.

The traditional technique used 30 to 40 layers of varnish which were then sanded to a polished finish (Encyclopedia Britannica, 2018)

The word decoupage comes from Middle French "decouper", meaning to cut out or cut from something. The origin of decoupage is thought to be East Siberian tomb art. (The coupage artist worldwide, 2018), Nomadic tribes used cut out felts to decorate the tombs of their deceased. From Siberia, the practice came to China, and by the 12th century, cut out paper was being used to decorate lanterns, windows, boxes and other objects. In the 17th century, Italy, especially Venice, was at the forefront of trade with the Far East and it is generally thought that it is through these trade links that the cut out paper decorations made their way into Europe (Marvin Gardens USA, 2010)

Decoupage juga dikenal sebagai seni dekorasi dengan cara menempel potongan-potongan kertas pada permukaan sebuah benda, kemudian dicat untuk memberikan efek yang diinginkan. Kemudian tidak lupa di-varnish agar potongan kertas seolah-olah benar 2 menyatu dengan objek tersebut. Kegiatan varnish ini dapat dilakukan berlapis-lapis sehingga mendapatkan efek menyatu.

\section{Pandemi Covid-19}

Coronavirus Diseases 2019 (Covid-

19) adalah penyakit jenis baru yang belum pernah diidentifikasi sebelumnya pada manusia, pada tanggal 30 Januari 2020 WHO telah menetapkan sebagai kedaruratan kesehatan masyarakat yang meresahkan dunia (Zhou et al., 2020).

World Health Organization menyatakan bahwa Coronaviruses (Cov) dapat menjangkit saluran nafas pada manusia. Virus tersebut memiliki nama ilmiah COVID-19. COVID-19 dapat memberikan efek mulai dari flu yang ringan sampai kepada yang sangat serius setara atau bahkan lebih parah dari MERS-CoV dan SARS-CoV (Kirigia \& Muthuri, 2020). COVID-19 disebut juga sebagai zoonotic yaitu penularannya ditularkan melalui manusia dan/atau hewan. Kementerian Kesehatan Republik Indonesia menyebutkan bahwa pandemi ini pertama kali terdeteksi di Wuhan, China yaitu pada tanggal 30 Desember 2019 yang ketika itu memberikan informasi berupa "pemberitahuan segera tentang pengobatan pneumonia dari penyebab yang tidak diketahui". COVID-19 menyebar begitu cepat ke seluruh penjuru dunia dan berubah menjadi pandemi yang horor bagi masyarakat dunia. Hingga penelitian ini ditulis ditemukan 93 negara yang telah terjangkit COVID-19. Pandemi COVID-19 yang telah menyebar pada akhirnya membawa risiko yang sangat buruk bagi perekonomian dunia termasuk Indonesia.

Menurut Gorbalenya Alexander, 2020), Pandemi COVID-19 adalah peristiwa menyebarnya Penyakit koronavirus 2019 (Bahasa Inggris: Coronavirus disease 2019, disingkat COVID-19) di seluruh dunia untuk semua Negara. Penyakit ini disebabkan oleh koronavirus jenis baru yang diberi nama SARS-CoV-2. Wabah COVID-19 pertama kali dideteksi di Kota Wuhan, Provinsi Hubei, Tiongkok pada tanggal 1 Desember 2019, dan ditetapkan sebagai pandemi oleh Organisasi Kesehatan Dunia (WHO) pada tanggal 11 Maret 2020.

Dalam rangka pencegahan menyebarnya virus corona, yaitu pembatasan perjalanan, karantina, pemberlakukan jam malam, dan social distancing.

METODE PELAKSANAAN 


\section{JURNAL ABDIMAS

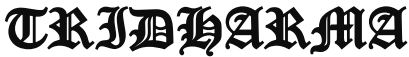

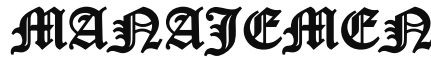

P-ISSN 2715-7105, E-ISSN 2716-070X

Jurnal ABDIMAS Vol. 2,No. 2, April 2021,Hal (80-90)

@Prodi Manajemen Fakultas Ekonomi Universitas Pamulang

Email: abdimasjurnal.unpam@gmail.com Telp: (021) 741-2566
Metode yang digunakan dalam kegiatan Pengabdian Kepada Masyarakat ini adalah penyuluhan tentang kreativitas untuk meningkatkan pendapatan warga dan praktek membuat kerajinan (craft) decoupage. Pengabdian dibagi menjadi dua yaitu tahap persiapan dan tahap pelaksanaan.

Tahap persiapan, meliputi:

1) Observasi dan survei ke Sekretariat Lembaga Pemberdayaan Masyarakat (LPM), Kelurahan Benda Baru, Kecamatan Pamulang, Kota Tangerang Selatan, beralamat di Kantor Kelurahan Benda Baru Pamulang, Jl. H. Rean No. 17, Pamulang, Tangerang Selatan, dan Aula Mesjid At-Taqwa 5 Benda Baru Pamulang Tangerang Selatan untuk tempat kegiatan Pengabdian Kepada Masyarakat, termasuk pengurusan perijinan untuk melaksanakan kegiatan tersebut.

2) Pemantapan konsep Pengabdian Kepada Masyarakat yang berupa penyuluhan mengenai meningkatkan kreativitas untuk meningkatkan pendapatan warga disertai pelatihan kerajinan (craft) decoupage, kepada warga Kelurahan RW 10 dan 12 Benda Baru Pamulang Tangerang Selatan. Pembuatan instrumen pelaksanaan kegiatan Pengabdian Kepada Masyarakat, berupa handout presentasi dan sampel praktek kerajinan (craft) decoupage.

3) Persiapan alat dan bahan, terdiri dari:

a) Alat dan bahan presentasi penyuluhan, seperti LCD (in focus), Laptop

b) Alat dan bahan pembuatan praktek kerajinan (craft) masker decoupage, berupa masker kain polos, tisu decoupage, lem, kuas dan gunting

Tahap Pelaksanaan, meliputi :

1) Penyuluhan

Tahap ini akan menjelasan tentang materi kreativitas untuk meningkatkan pendapatan warga, dengan membuat produk sesuai kebutuhan pada masa ini dan memiliki daya jual tinggi dan memberikan rasa optimis untuk dapat berdaya saing tinggi dimasa pandemi covid-19, selanjutnya dilakukan diskusi dan tanya jawab

2) Tahap Pelatihan/Praktek

Untuk melaksanakan kegiatan tersebut digunakan beberapa metode pelatihan, yaitu :

a. Metode Demonstrasi

Metode demonstrasi ini menunjukkan contoh kepada para peserta untuk mengerjakan/praktek membuat kerajinan (craft) masker decoupage dari bahan kain untuk membuat masker dengan corak menarik.

b. Metode Tanya Jawab

Metode tanya jawab sangat penting bagi para peserta pelatihan. Metode ini memberi kesempatan kepada peserta untuk menanyakan hal-hal yang masih kurang/belum jelas untuk dipraktekkan nanti.

c. Metode Simulasi

Metode simulasi ini diberikan kepada para peserta pelatihan untuk mempraktekkan membuat kerajinan (craft) masker decoupage dari bahan kain dengan motif tissu decoupage yang menarik

\section{HASIL DAN PEMBAHASAN Hasil Kegiatan}

Warga Kelurahan Benda Baru Pamulang, khususnya RW 06, RW 10 dan RW 12 mengikuti penyuluhan dan pelatihan dengan semangat dan antusias yang tinggi, sehingga acara berlangsung efektif dengan hasil kegiatan yang bermanfaat dan memuaskan. Para peserta merupakan perwakilan warga yang terpilih dari masingmasing RW, dengan tujuan sebagai mentor atau training for trainer untuk bisa memberikan dan mengimplementasikan ilmu yang didapat kepada warga lainnya, yang belum berkesempatan hadir, sebagai duta warga. Warga antusias memperhatikan dan mencatat point-point penting, sehingga semua ilmu dan informasi dapat terekam dan terdokumentasi untuk warga lainnya.

Dalam pelatihan ini, team PKM memberikan sharing knowledge mengenai kreativitas. Kemudian peserta melakukan praktek membuat sendiri kerajinan (craft) 


\section{JURNAL ABDIMAS

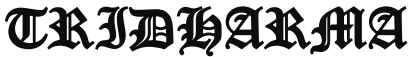 AtA}

P-ISSN 2715-7105, E-ISSN 2716-070X

Jurnal ABDIMAS Vol. 2,No. 2, April 2021,Hal (80-90)

@Prodi Manajemen Fakultas Ekonomi Universitas Pamulang

Email: abdimasjurnal.unpam@gmail.com Telp: (021) 741-2566 decoupage dengan produk masker, yang mempunyai media bahan dasar kain katun yang nyaman. Dampak kegiatan pemberdayaaan warga Kelurahan Benda Baru Pamulang ini, melalui kerajinan (craft) decoupage akan menambah kreativitas dan ketrampilan untuk menciptakan produk yang mempunyai nilai seni dan nilai jual tinggi, produk disesuiakan dengan kondisi dan kebutuhan pasar, yang saat ini dalam kondisi pandemi dan new normal. Diharapkan dapat meningkatakan pendapatan warga.

Di akhir acara, untuk menguji pemahaman dan kemampuan peserata, kami memberikan quiz berupa pertanyaan, antara lain tahap-tahap pembuatan dan lainnya. Tentunya, untuk menghidupkan suasana, kami memberikan gift untuk peserta yang berhasil menjawab pertanyaan dengan benar dan lengkap. Kemudian memberikan penilaian dan memilih peserta yang berhasil membuat produk masker yang paling indah, rapi dan menarik, untuk dinobatkan sebagai juara. Sesi question and answer atau tanya jawab sangat menarik, karena peserta antusias memberikan pertanyaan. Satu hal terpenting adalah Ketua LPM dan Ketua RW mempunyai spirit dan semangat yang luar biasa untuk pemberdayaan warganya, sehingga beliau melengkapi informasiinformasi yang diperlukan oleh kami, maupun peserta untuk kemajuan bersama.

\section{Pembahasan}

Tempat kegiatan PKM adalah di Aula Masjid At-Taqwa 5 Kelurahan Benda Baru Pamulang, Tangerang Selatan, dengan jumlah peserta sebanyak 25 orang.

Hari pertama, Sabtu, 14 Nopember 2020 Kegiatannya berupa penyuluhan dengan penyampaian materi tentang meningkatkan kreativitas dan pendapatan warga Benda Baru Pamulang pada masa pandemi dengan tujuan untuk meningkatkan jiwa kreatifitas dan pengetahuan untuk meningkatkan pendapatan warga, selanjutnya dilakukan tahap diskusi dan tanya jawab. Penyampaian materi diberikan oleh tim PKM.

\section{Hari kedua, Minggu, 15 Nopember 2020}

Kegiatan berupa pelatihan, dengan pengenalan bahan dan alat kemudian dijelaskan bagaimana teknik membuat decoupage dengan media masker kain dengan berbagai corak seperti bunga dan batik.

Bahan dan alat yang digunakan untuk membuat kerajinan decoupage :

1. Tisu bermotif bunga dan batik

2. Masker kain polos

3. Lem \& vernish kain decoupage

5. Kuas kecil

7. Gunting

8. Hair dryer/kipas angin mini

Proses Pembuatan Masker Decoupage

a. Siapkan media yang ingin dihias dengan decoupage, yaitu masker kain polos

b. Guntinglah lembaran-lembaran kertas tisu, seluruh lembaran kertas, bisa disobek, atau digunting agar tercipta bentuk dan desain yang menarik. Ambil lembaran yang terakhir (tipis).

c. Gunakan lem untuk permukaan objek (masker kain polos) sehingga kertas tisu.menempel dengan baik.

d. Oleskan lem menggunakan kuas dengan tipis dan merata pada masker kain.

e. Tempelkan satu per satu potongan kertas tisu yang sudah dibentuk sesuai kreasi masing masing pada permukaan masker kain. Letakkan potongan kertas pada area yang sudah dibubuhi lem dengan hatihati agar tidak timbul lipatan atau kekusutan, lalu keringkan dengan menggunakan hair dryer/kipas angin mini.

f. Setelah kering, oleskan kembali lem decoupage di atas permukaan kertas tisu dengan hati-hati supaya tidak robek lalu biarkan sampai kering

h. Selesai

Penyampaian materi pelatihan praktek kerajinan (craft) decoupage diberikan oleh tim PKM.

Hasil pelaksanaan PKM juga diukur berdasarkan jawaban angket pertanyaan dari peserta pelatihan sejumlah 19 orang dari 25 peserta, tentang: materi pelatihan, fasilitator, tempat pelatihan dan 


\section{JURNAL ABDIMAS

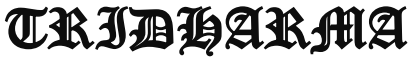

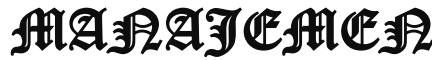

P-ISSN 2715-7105, E-ISSN 2716-070X

Jurnal ABDIMAS Vol. 2,No. 2, April 2021,Hal (80-90)

@ Prodi Manajemen Fakultas Ekonomi Universitas Pamulang

Email: abdimasjurnal.unpam@gmail.com Telp: (021) 741-2566 sajian/konsumsi selama pelatihan yang diukur menggunakan penilaian skala 1 sampai 5 berikut:

\section{Tabel 1. Skala jawaban responden} pelatihan

\begin{tabular}{|l|l|}
\hline & Kriteria \\
\hline $4,21-5,00$ & Sangat Baik \\
\hline $3,41-4,20$ & Baik \\
\hline $2,61-3,40$ & Cukup \\
\hline $1,81-2,60$ & Kurang \\
\hline $1,00-1,80$ & Kurang Sekali \\
\hline
\end{tabular}

Tabel 2. Penilaian Responden Terhadap

\section{Pelaksanaan Pelatihan}

\begin{tabular}{|c|c|c|c|c|c|c|c|c|}
\hline No & $\begin{array}{l}\text { Penilaian } \\
\text { Kegiatan }\end{array}$ & 5 & 4 & 3 & 2 & 1 & $\mathrm{Jmh}$ & Skor \\
\hline A & Materi Pelatihan & & & & & & & \\
\hline 1 & $\begin{array}{l}\text { Jelas dan mudah } \\
\text { diikuti }\end{array}$ & 13 & 4 & 2 & 0 & 0 & 19 & 87 \\
\hline \multirow[t]{2}{*}{2} & $\begin{array}{l}\text { Relevan dengan } \\
\text { objektivitas } \\
\text { pelatihan }\end{array}$ & 12 & 5 & 2 & 0 & 0 & 19 & 86 \\
\hline & Sub Total_1 & 25 & 9 & 4 & 0 & 0 & 38 & $173 \mathrm{D}$ \\
\hline B & Fasilitator & & & & & & & \\
\hline 1 & $\begin{array}{l}\text { Penguasaan } \\
\text { materi }\end{array}$ & 13 & 4 & 2 & 0 & 0 & 19 & $87 \mathrm{~V}$ \\
\hline 2 & $\begin{array}{l}\text { Gaya } \\
\text { penyampaian }\end{array}$ & 12 & 5 & 2 & 0 & 0 & 19 & $86 \mathrm{de}$ \\
\hline 3 & $\begin{array}{l}\text { Kejelasan dalam } \\
\text { penyampaian }\end{array}$ & 10 & 7 & 2 & 0 & 0 & 19 & $84 \mathrm{SC}$ \\
\hline 4 & $\begin{array}{l}\text { Kemampuan } \\
\text { dalam menjawab } \\
\text { pertanyaan }\end{array}$ & 13 & 4 & 2 & 0 & 0 & 19 & 87 ury \\
\hline \multirow[t]{2}{*}{5} & Penampilan & 12 & 4 & 3 & 0 & 0 & 19 & $85 \mathrm{me}$ \\
\hline & Sub Total_2 & 60 & 24 & 11 & 0 & 0 & 95 & $429 \mathrm{fas}$ \\
\hline $\mathrm{C}$ & $\begin{array}{l}\text { Tempat } \\
\text { Pelatihan }\end{array}$ & & & & & & & \\
\hline \multirow[t]{2}{*}{1} & $\begin{array}{l}\text { Kenyamanan } \\
\text { dalam belajar }\end{array}$ & 10 & 7 & 2 & 0 & 0 & 19 & $84 \mathrm{Pe}$ \\
\hline & Sub Total_2 & 10 & 7 & 2 & 0 & 0 & 19 & $84 \mathrm{ad}$ \\
\hline D & Sajian/Konsumsi & & & & & & & \\
\hline 1 & Coffe break/snack & 11 & 4 & 4 & 0 & 0 & 19 & 83 \\
\hline 2 & Makan Siang & 9 & 3 & 7 & 0 & 0 & 19 & 78 \\
\hline & Sub Total_2 & 20 & 7 & 11 & 0 & 0 & 38 & 1612. \\
\hline & $\begin{array}{l}\text { Kesimpulan } \\
\text { Umum Pelatihan }\end{array}$ & 115 & 47 & 28 & 0 & 0 & 190 & 847 \\
\hline
\end{tabular}

5. Baik Sekali , 4. Baik, 3. Cukup, 2. Cukup, 1. Kurang Sekali

Berdasarkan hasil jawaban 19 responden dari 25 peserta pelatihan pada tabel 2 di atas, diperoleh hasil sebagai berikut:

1. Materi pelatihan yang meliputi kejelasan materi, mudah diikuti dan relevan dengan obyektivitas pelatihan yang dilaksanakan diperoleh skor nilai 4,55 dengan kriteria sangat baik karena terletak diantara skor 4,21 sampai 5,00.

2. Fasilitator pelatihan dalam hal penguasaan materi, gaya penyampaian, kejelasan materi, penampilan dan kemampuan menjawab pertayaan peserta diperoleh skor nilai 4,52 dengan kriteria sangat baik karena terletak diantara skor 4,21 sampai 5,00.

3. Tempat pelatihan dalam hal ini kenyamanan peserta selama peserta mengikuti pelatihan tergolong sangat baik dengan skor nilai 4,42 dan terletak diantara skor 4,21 sampai 5,00.

Sajian/konsumsi dalam hal penyediaan coffee break/snack dan makan siang peserta diperoleh skor nilai 4,24 dengan kriteria sangat baik karena terletak diantara skor 4,21 sampai 5,00.

hasil pelaksanaan pelatihan "meningkatkan kreativitas dan pendapatan "rga Kelurahan Benda Baru Pamulang" pelaksanaan praktek kerajinan coupage, di dapatkan hasil rata-rata ara keseluruhan diperoleh nilai 4,46 atagori pelatihan "sangat baik". Adapun urutan evaluasi pelaksanaan kegiatan pelatihan dari yang tertinggi hingga terendah 85 meliputi: materi pelatihan skor 4,55, asilitator dengan skor 4,52, tempat pelatihan dengan skor 4,42 dan sajian/konsumsi dengan skor 4,24. Pembasahan dari hasil survey peserta PKM lah sebagai berikut:

Materi pelatihan yang diberikan kepada peserta sangat baik karena materi disampaikan dengan jelas, mudah diikuti dan relevan dengan peserta.

Fasilitator pelatihan dangat baik dalam menguasai materi, cara/gaya penyampaian, kejelasan materi, penampilan dan kemampuan dalam menjawab permasalahan yang disampaikan oleh peserta.

3. Tempat pelatihan sangat baik, karena peserta merasa nyaman dalam mengikuti seluruh kegiatan pelatihan dari awal sampai akhir. 


\section{JURNAL ABDIMAS

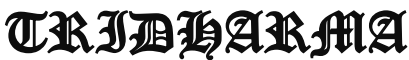

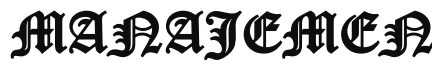

P-ISSN 2715-7105, E-ISSN 2716-070X

Jurnal ABDIMAS Vol. 2,No. 2, April 2021,Hal (80-90)

@ Prodi Manajemen Fakultas Ekonomi Universitas Pamulang

Email: abdimasjurnal.unpam@gmail.com Telp: (021) 741-2566
4. Konsumsi dan coffe break/snack yang disediakan sangat baik.

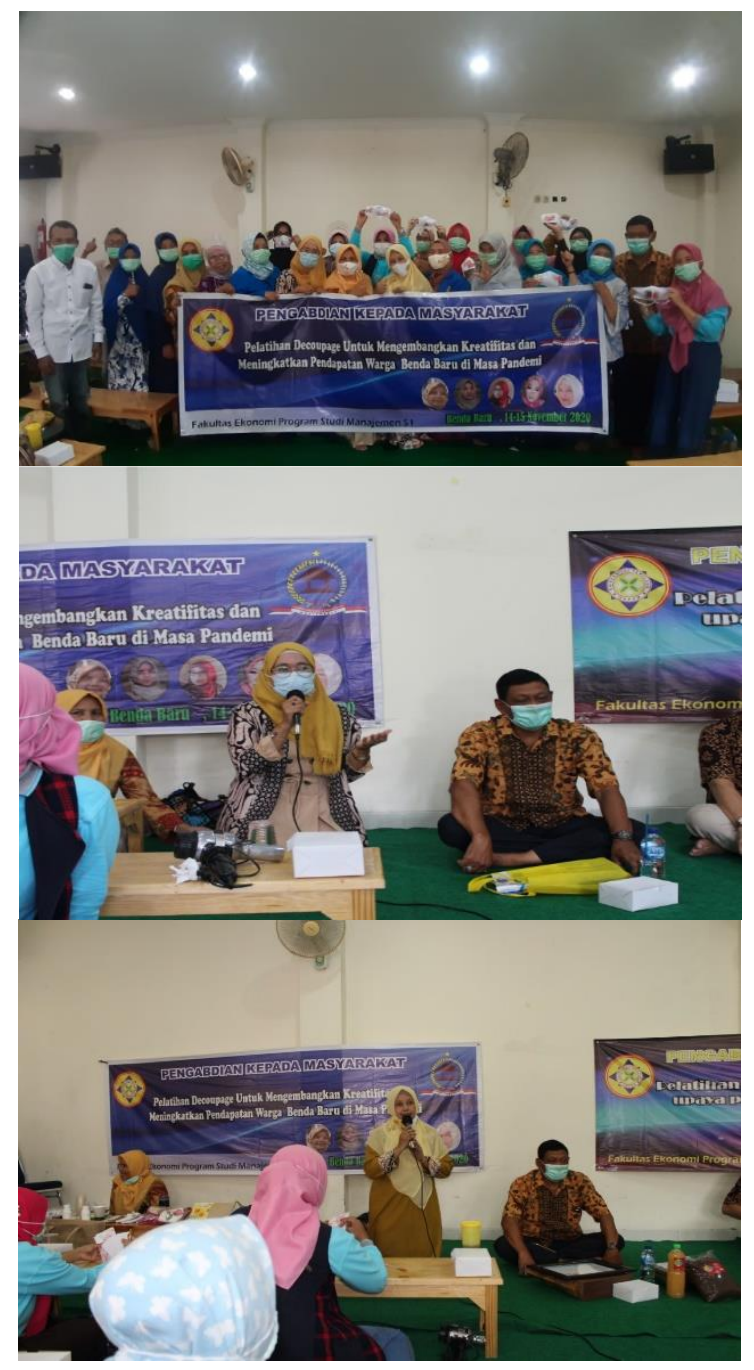

\section{KESIMPULAN DAN SARAN}

\section{Kesimpulan}

1. Penyuluhan mengenai mengembangkan kreativitas dan meningkatkan pendapatan warga Kelurahan Benda Baru Pamulang dapat memotivasi untuk optimis menciptakan ide baru dan meningkatkan pendapatan warga, khususnya pada masa pandemi Covid-19 ini.

2. Pelatihan/praktek pembuatan kerajinan (craft) masker kain decoupage membuat warga Kelurahan Benda Baru Pamulang, mampu dan berani menciptakan/menangkap peluang usaha di masa pandemi Covid 19 ini.

\section{Saran}

1. Adanya evaluasi dan pemantauan secara berkala setelah adanya pelatihan pada warga Kelurahan Benda Baru Pamulang untuk mengukur efektifitas dari pelatihan yang telah diberikan.

2. Melakukan pelatihan berkelanjutan untuk membina warga Kelurahan Benda Baru Pamulang.

3. Melakukan pelatihan praktek $e$ commerce untuk implementasi dari penjualan produk secara nyata berbasis online.

\section{DAFTAR PUSTAKA}

Aditia, Dito, dkk. (2020), Dampak Pandemi Covid-19 Terhadap, Jurnal Benefita 5 (2) Juli $2020 \quad$ (212-224) LLDIKTI Wilayah X 21

Andriani, Jeni, R. Wulansari, SR Sampurnaningsih, Nofiar, F. Sabina. (2020). Pemberdayaan Ibu PKK RW 05 Kelurahan Kuningan Barat Jakarta Selatan Melalui Pelatihan Manajemen Usaha Kerajinan (Craft) Decoupage Untuk Meningkatkan Ekonomi Keluarga. Jurnal Lokabmas Kreatif 1 (1). 15-20

Depdiknas. (2003). Kamus Besar Bahasa Indonesia, Edisi Ketiga, Jakarta: Penerbit Balai Pustaka.

Elburdah, R. P., Pasaribu, V. L. D., Rahayu, S., Septiani, F., \& Metarini, R. R. A. (2021). MOMPRENEUR PENOPANG PEREKONOMIAN KELUARGA DI MASA PANDEMI COVID-19 DENGAN BISNIS ONLINE PADA KELURAHAN PONDOK BENDA. Abdi Laksana: Jurnal Pengabdian Kepada Masyarakat, 2(1), 75-82.

Endang Hariningsih dan Rintar Agus Simatupang. (2008). Faktor-Faktor Yang Mempengaruhi Kinerja Usaha Pedagang Eceran Studi Kasus: Pedagang Kaki Lima Di Kota Yogyakarta. Jurnal Bisnis \& Manajemen Vol. 4, No. 2, 2008 Fakultas Ekonomi Manajemen Universitas Andalas, Hal 29

Hendrik. (2011). Analisis Pendapatan dan Tingkat Kesejahteraan Masyarakat nelayan danau pulau besar dan danau 


\section{JURNAL ABDIMAS

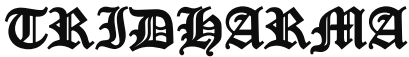

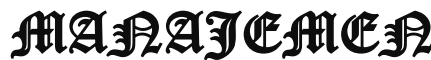

P-ISSN 2715-7105, E-ISSN 2716-070X

Jurnal ABDIMAS Vol. 2,No. 2, April 2021,Hal (80-90)

@Prodi Manajemen Fakultas Ekonomi Universitas Pamulang

Email: abdimasjurnal.unpam@gmail.com Telp: (021) 741-2566 bawah di kecamatan Dayun Kabupaten Siak Provinsi Riau. Jurnal Perikanan dan Kelautan 16,1 : 21-32

Maswarni, Jeni, Retno W, SR Sampurnaningsih, N. Susanti. (2020). Membentuk Entrepreneur Generasi Muda Untuk Membangun Percaya Diri Dalam Menghadapi Tantangan Masa Depan Pada Yayasan Islahul Hayat Rumah Yatim \& Dhuafa Kelurahan Bambu Apus Kecamatan Pamulang Tangerang Selatan. Jurnal Lokabmas Kreatif 1 (3), 7-15

Munandar, Utami (1995) Pengembangan Kreativitas Anak Berbakat. Jakarta: P.T Rineka Cipta.

Munandar, M. (2006). Pokok-pokok Intermediate Accounting. Yogyakarta: Gajah Mada.

Munandar, Utami. (2009). Pengembangan kreativitas anak berbakat. Jakarta:Rineka cipta

Pasaribu, V. L. D., Agrasadya, A., Shabrina, N., \& Krisnaldy, K. (2020). Menjadi Enterpreneur Muda Yang Memiliki Jiwa Leadership Untuk Menghadapi Masa Depan. Abdi Laksana: Jurnal Pengabdian Kepada Masyarakat, 1(1).

Poniwati, Asmie. (2008). Analisis FaktorFaktor Yang Mempengaruhi Tingkat Pendapatan Pedagang Pasar Tradisional di Kota Yogyakarta. Yogyakarta : Universitas Gajah Mada.

Samuelson, Paul A. dan William D. Nordhaus, (2002). Ilmu Makroekonomi. Edisi Ketujuh belas. Jakarta: PT. Media Global Edukasi

Sukirno, Sadono. (2000). Makro Ekonomi Teori Pengantar. Jakarta: Raja Grafindo Perkasa.

Suparmoko, M. (2000). Pengantar Ekonomi Makro, BPFE, Jakarta.

Tjandra, Hendraidjat. (2016). Berkreasi Berbagi Teknik Decoupage Bersama Inspiration Craft. Jakarta : Gramedia Pustaka Utama

Tohar, M., (2003). Membuka Usaha Kecil. Yogyakarta: Kanisius

\section{Website :}

"WHO Director-General's opening remarks at the media briefing on COVID-19-11
March 2020". www.who.int.. Diakses tanggal 10 Januari 2021.

"The History of Decoupage". Marvin Gardens USA. Diakses tanggal 15 Januari 2021.

"Decoupage|art". Encyclopedia Britannica. Diakses tanggal 15 Januari 2021.

Miquel Porta (2008). Miquel Porta, ed. Dictionary of Epidemiology. Oxford University Press. hlm. 179. ISBN 978-019-531449-6. Diakses tanggal 14 Januari 2021.

"WHO says it no longer uses 'pandemic' category, but virus still emergency". Reuters (dalam bahasa Inggris). Diakses tanggal 9 Januari 2021. 